\title{
Coagulation-Flocculation of Leachate by Using Single Coagulant Made from Chemical Coagulant (Polyaluminium Chloride) and Natural Coagulant (Tapioca Flour)
}

\author{
M. Z. N. Shaylinda ${ }^{1,2,3, *}$, R. Taruunen', Z. A. M. Hazreek ${ }^{1}$, W. M. W. Afnizan ${ }^{1}$ \\ ${ }^{1}$ Faculty of Civil and Environmental Engineering, \\ Universiti Tun Hussein Onn Malaysia, 86400 Parit Raja, Johor, MALAYSIA \\ ${ }^{2}$ Micro Pollutant Research Center, \\ Universiti Tun Hussein Onn Malaysia, 86400 Parit Raja, Johor, MALAYSIA \\ ${ }^{3}$ School of Environmental Science and Engineering, \\ Chang'an University, No. 126, Yanta Road, Yanta District, Xi'an, Shaanxi Province, CHINA \\ *Corresponding Author
}

DOI: https://doi.org/10.30880/ijie.2019.11.06.025

Received 25 January 2019; Accepted 18 June 2019; Available online 01 September 2019

\begin{abstract}
Application of coagulation and flocculation in leachate treatment is common nowadays. Chemical coagulant is commonly applied compared to natural coagulant. Thus, this study compared the effectiveness of landfill leachate treatment by single coagulant which are chemical and natural coagulant through the removal of suspended solid (SS), sludge settling rate and sludge volume index. The experiment was carried out using standard jar test method and raw leachate sample was collected from Landfill Simpang Renggam. The chemical coagulant used was polyaluminium chloride and natural coagulant was Tapioca flour. Tapioca flour has characteristic as coagulant where it has sticky characteristic that can remove pollutant in leachate without leaving any side effects latter and it is available in abundance, cheaper, and environmentally friendly. Result of this study shown that, the optimum dosage and $\mathrm{pH}$ of PAC was $3 \mathrm{~g} / \mathrm{L}$ at $\mathrm{pH} 8$ and for tapioca flour was $1 \mathrm{~g} / \mathrm{L}$ at $\mathrm{pH} 4$. The percentage removal by PAC as in term of removal of suspended solid, sludge volume index and sludge settling rate were $94 \%, 5273 \mathrm{~mL} / \mathrm{gm}$ and 1.58 $\mathrm{cm} / \mathrm{min}$, respectively. While, for tapioca flour there was minimal sludge formation and the removal of SS was $13.3 \%$. The particles size for sludge leachate after treatment for optimum dose was in range of $20 \mu \mathrm{m}$ and the floc were arranged compacted, and shaped elongated. Hence, this study shows that PAC is more effective than Tapioca flour as single coagulant in terms of sludge volume index, sludge settling rate, removal of suspended solid and particle size of sludge.
\end{abstract}

Keywords: Malaysia landfill, bio-coagulant, organic coagulant

\section{Introduction}

Nowadays, increasing in solid municipal solid waste has causes some serious circumstances to the country. The increase in the population and urbanization resulted in tremendous amount of solid waste generation. This implication requires a better handling solution to reduce the generation of waste. A regular waste management framework in a country demonstrates numerous issues, including low accumulation scope and crucial gathering management, untreated open 
dumping and consuming without air and water contamination control and control of casual waste picking or rummaging exercises [1]. Furthermore, a better classification system for landfills is needed to address inconsistencies in data for sanitary landfill sites. Changes in municipal solid waste generation rates are mostly caused by the demographic factors sand facilities which are provided by the respective department. In addition, the composition of municipal solid waste in Malaysia extremely non-homogenous and varied caused by difference between cities as the level of industrialization and consuming habits. This signify the level of urbanization and rapid development of the country. Leachate is referred to as high quality wastewater framed because of permeation of water and dampness through waste [2] and may cause significant pollution.

Decomposing waste at the landfill site create major environmental problems. Landfill leachate categorized as high strength wastewater with large variables of organic, inorganics and heavy metal. The water quality affected as leachate percolates and mixs surface run off [3]. The high concentration of ammonia and heavy metals in leachate affected the biological process of microorganism [4]. The quality of landfill leachate depends on several factors such as composition and types of waste, moisture and oxygen content, design and operation of landfill sites and age of landfill [4]. Due this problem, Malaysia is facing a difficulty to obtain a satisfactory treatment for landfill leachate.

The primitive pollutant of leachate is dissolved organic matter, inorganic macro components, heavy metals, and xenobiotic organic compounds. To minimize toxicity and hazardous material content of landfill leachate before discharged into the environment, various methods were used to treat leachate such as biological treatment, chemical and physical treatment, and combined treatment [5].

Coagulation/flocculation is commonly applied for water and wastewater treatment. This method is also classified as conventional treatment method. It involved simple process. One of the main factors determining the effectiveness of this system is the coagulant. Coagulant can be divided into chemical and natural coagulant. Chemical coagulant is made from chemical material and commercially available such as alum, polyaluminium chloride, polyferric chloride and ferric chloride [6]. While natural coagulant or natural polymer is organic and consist of polysaccharides and proteins elements [7]. Both types, has difference efficiency performance. Thus, it is important to know how effective each of coagulant react toward leachate. The purpose of this paper is to study the effectiveness of two different coagulant (PAC and Tapioca Flour) on the removal of suspended solid, sludge volume index and sludge settling rate for leachate treatment.

\section{Methodology}

The landfill leachate used in this study was taken from Simpang Renggam municipal landfill site in Johor. The total area of the landfill is 28 hectares. The landfill has been operating for 10 years. Simpang Renggam municipal landfill received about 250 tonnes of solid waste every day from three different districts. All analytical procedures were performed according to the Standard Method of Water and Wastewater APHA [8]. The collection of leachate was using a pump (submersible pump) which submerged at a depth $0.3 \mathrm{~m}$ from the surface of leachate. Samples were transported to the laboratory of Civil and Environment Engineering Analysis, Universiti Tun Hussein Onn Malaysia (UTHM) and stored at $4^{\circ} \mathrm{C}$ for further analyses. Coagulation and flocculation process were performed in a standard jar-test apparatus.

The characteristics of landfill leachate measured in this study is shown in Table 1. The leachate is considered as old leachate and stabilized leachate (Table 2). For this type of leachate, the favorable treatment method is physical/chemical, such as coagulation/flocculation. Thus, Simpang Renggam leachate suit the method proposed for this study.

Sodium chloride and sulfuric acid were used to adjust the $\mathrm{pH}$ of the leachate $(1000 \mathrm{ml})$. The prescribed dose of coagulant was added to each jar. At beginning, start stirring rapidly with (200 rpm) for 4 minutes (Rapid mixing stage). After that, reduced the speed to $30 \mathrm{rpm}$ for 15 minutes. Supernatant was collected after 30 minutes of settling time. At the end of settling, sample of sludge was collected for SEM measurement. To determine the sludge volume index (SVI) equation 1 was used to plot the graph.

$$
S V I=\frac{(S V / V)}{\sum S S} \times 1000
$$

where $S V I$ is in $\mathrm{mL} / \mathrm{gm}, S V$ is the settle sludge volume in $(\mathrm{mL}), V$ is volume of sample in $L$ and $\Sigma S S$ is the total suspended solids in $\mathrm{mg} / \mathrm{L}$.

For determination sludge settling rate $(S S R)$, the sludge was allowed to settle and measured according to time intervals. Then, plotted sludge height versus time. The sludge settling rate was determine by using following formula:

$$
V S=\frac{m h}{V}
$$

where $V S$ is the velocity sludge, $m$ is slope of the graph, $h$ is initial height of sludge and $V$ is initial volume of sludge. 
Table 1 - Characteristics of Simpang Renggam landfill leachate.

\begin{tabular}{lc}
\hline \multicolumn{1}{c}{ Parameter } & Initial Characteristics \\
\hline Suspended Solids (SS)(mg/L) & $123-166$ \\
Turbidity (NTU) & $25-80.1$ \\
Colour (Pt.Co) & $2400-7200$ \\
pH & $7.68-8.60$ \\
BOD/COD & 0.05 \\
Ammonia (mg/L) & 920 \\
Number of sample & 6 \\
Duration of sampling & February - April 2018 \\
\hline
\end{tabular}

Table 2 - Characteristic of leachate based on age [9].

\begin{tabular}{|l|c|c|c|}
\hline Leachate type & Young & Medium & Old \\
\hline Landfill age area & $<5$ & $5-10$ & $>10$ \\
\hline $\mathrm{pH}$ & $<6.5$ & 7 & $>7.5$ \\
\hline $\mathrm{COD}(\mathrm{mg} / \mathrm{L})$ & $>10,000$ & $4,000-10,000$ & $<4,000$ \\
\hline BOD 5 /COD & $0.5-1.0$ & $0.1-0.5$ & $<0.1$ \\
\hline TOC/BOD & $<0.3$ & $0.3-0.5$ & $>0.5$ \\
\hline $\begin{array}{l}\text { Ammonia nitrogen } \\
(\mathrm{mg} / \mathrm{L})\end{array}$ & $<400$ & $>400$ \\
$\begin{array}{l}\text { Heavy metals } \\
(\mathrm{mg} / \mathrm{L})\end{array}$ & $\begin{array}{c}\text { Low - } \\
\text { Biodegradability }\end{array}$ & Ledium & Low \\
\hline
\end{tabular}

\section{Results and Discussion}

\subsection{PAC}

The initialization of the experiments was carried out with optimization doses of PAC as single coagulant, the $\mathrm{pH}$ of sample was set to 7 . Doses of PAC with range $1 \mathrm{~g} / \mathrm{L}-6 \mathrm{~g} / \mathrm{L}$ was used in this study. According to measured data, doses of PAC at $4 \mathrm{~g} / \mathrm{L}$ and $3 \mathrm{~g} / \mathrm{L}$ show great removal as shown in Fig. 1. The removal differences between dose $3 \mathrm{~g} / \mathrm{L}$ and $4 \mathrm{~g} / \mathrm{L}$ were not large. Thus, $3 \mathrm{~g} / \mathrm{L}$ was selected as optimum dose due to economical factor and less dose usage. The optimum dose of PAC in term of SVI and SSR with varied dosage were shown in Fig. 2 and Fig. 3. Hence, the result for optimum dosage of dose $3 \mathrm{~g} / \mathrm{L}$ in terms of suspended solid removal, SVI and SSR were as $98 \%, 4561 \mathrm{~mL} / \mathrm{gm}$, and $0.8 \mathrm{~cm} / \mathrm{min}$, respectively. Removal of SS in this study is similar with Ghafari et al. [10].

The removal of suspended solid increased as the dosage of PAC increased until the trend reached the optimum at 99\% removal (dose $4 \mathrm{~g} / \mathrm{L}$ ) and after that the removal gradually decreased. This has been supported with justification by Hamidi et al. [11] as excessive amount of coagulant causes re-stabilization of colloid instead of re-dispersion of the colloidal particles actually occurs.

Moreover, according to Noor Ainee et al. [12] amount of coagulant depends on magnitude of electrical charge on the colloidal particles and if there are more organic matter with negative charges, larger coagulant amount needed. Furthermore, with increasing in coagulant dose, SVI also increased gradually (Fig. 2).

Furthermore, the faster SSR is at dose $1 \mathrm{~g} / \mathrm{L}$ and the slowest SSR is at dose $5 \mathrm{~g} / \mathrm{L}$, apparently in terms of removal of SS at dose $1 \mathrm{~g} / \mathrm{L}$ was $49 \%$ and dose $5 \mathrm{~g} / \mathrm{L}$ was at $89 \%$ (Fig. 1). However, the highest removal of SS for dose $4 \mathrm{~g} / \mathrm{L}$ and dose $3 \mathrm{~g} / \mathrm{L}$ were $99 \%$ and $98 \%$, respectively (Fig. 1). Based on the data, as more dose of chemical coagulant added, it decreased the SSR and increased the floc growth [13]. High coagulant dose is favorable in removing suspended solid and it is adverse for settling process since it reduces the sludge settling rate, generating larger volume of compacted sludge [14].

After varying the coagulant concentrations of PAC further test was carried out by testing different $\mathrm{pH}$ of samples in the range of 3 to 8 at dosage $3 \mathrm{~g} / \mathrm{L}$ and $4 \mathrm{~g} / \mathrm{L}$ of PAC. For $3 \mathrm{~g} / \mathrm{L} \mathrm{PAC}$, with the change of the $\mathrm{pH}$, the highest suspended solids removal rate was achieved at $\mathrm{pH} 7$. While, $\mathrm{pH} 8$ recorded $94 \%$ removal as shown in Fig. 4. From the result of the analysis, the highest removal of suspended solid was at $\mathrm{pH} 7$, with $99 \%$ removal. In terms of SVI, pH 3-6 were neglected due to high acidic content and $\mathrm{pH}$ 7-8 were taken into consideration. It was found out that the SVI values for $\mathrm{pH} 7$ is higher than $\mathrm{pH} 8$ and signify that $\mathrm{pH}$ 8produced less and thicker sludge, consolidated sludge and the settling rate also 
was faster than $\mathrm{pH} 7$ as shown in Fig. 5 and Fig. 6. Hence, pH 8 was selected as optimum pH. Optimum pH selected is within the range of initial $\mathrm{pH}$ of leachate (Table 1), thus reducing the cost of $\mathrm{pH}$ adjustment during treatment.

As for dose $4 \mathrm{~g} / \mathrm{L}$ the highest removal of suspended solid for varied $\mathrm{pH}$ was at $\mathrm{pH} 8(98 \%)$ as shown in Fig. 7. While, pH 7 achieved 97\% suspended solid removal. SVI value for $\mathrm{pH} 8$ and $\mathrm{pH} 7$ were $4439 \mathrm{~mL} / \mathrm{gm} \mathrm{and} 3886 \mathrm{~mL} / \mathrm{gm}$, respectively. As for, SSR value of $\mathrm{pH} 8$ and $\mathrm{pH} 7$ were 0.4 and 0.43 , respectively (Fig. 8). The sludge settling rate of $\mathrm{pH}$ 7 and $\mathrm{pH} 8$ were not much differs (Fig. 9) and it settles at same rate and as well as SVI too. Hence, pH 7 recorded less value of SVI and higher value of SSR compared to $\mathrm{pH}$ 8. Thus, $\mathrm{PH} 7$ is selected as optimum $\mathrm{pH}$ for dose $4 \mathrm{~g} / \mathrm{L}$.

SVI lower value is preferable for coagulation treatment as it able to reduce the sludge volume and directly reduce the sludge treatment cost. While for SSR, highest value is needed for faster treatment duration. However, the selection of optimum condition should consider overall factors, which are suspended solid removal, SSR and SVI. Thus, pH 8 at dose $3 \mathrm{~g} / \mathrm{L}$ is selected as optimum condition for PAC.

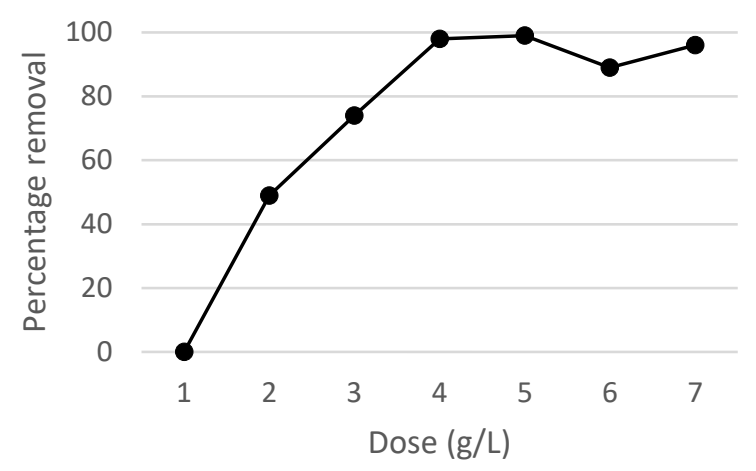

Fig. 1 - Removal of suspended solid of varied dose of PAC at pH 7.

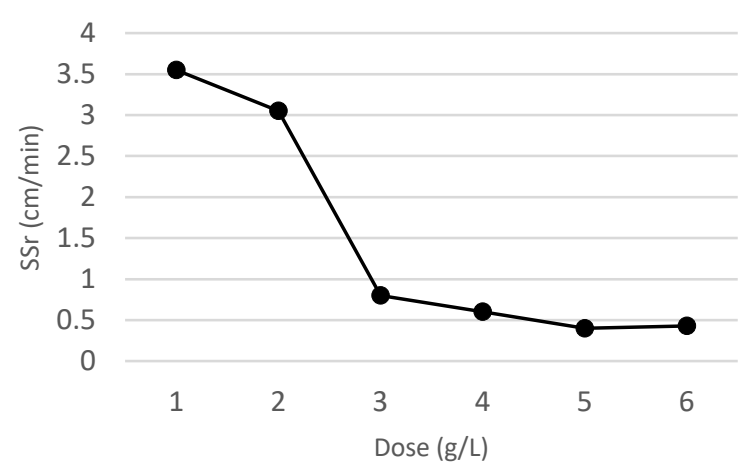

Fig. 3 - SSR of varied dose of PAC at pH 7.

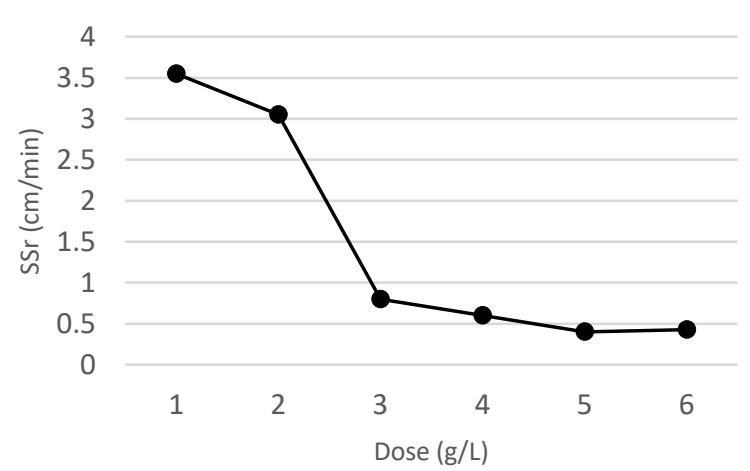

Fig. 3 - SSR of varied dose of PAC at pH 7.

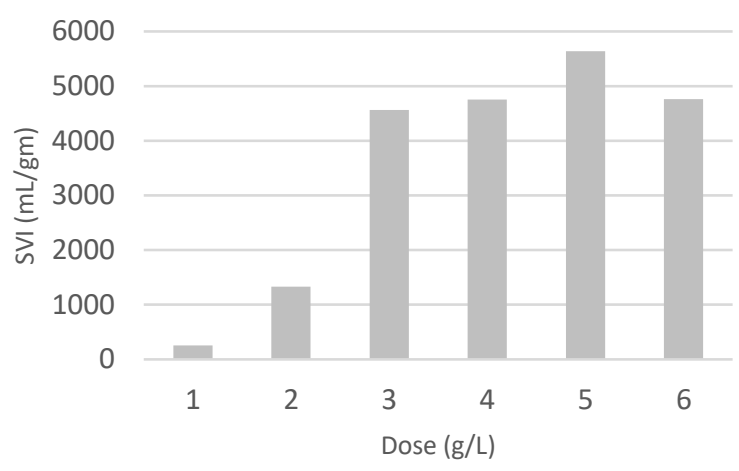

Fig. 2 -SVI of varied dose of PAC at pH 7.

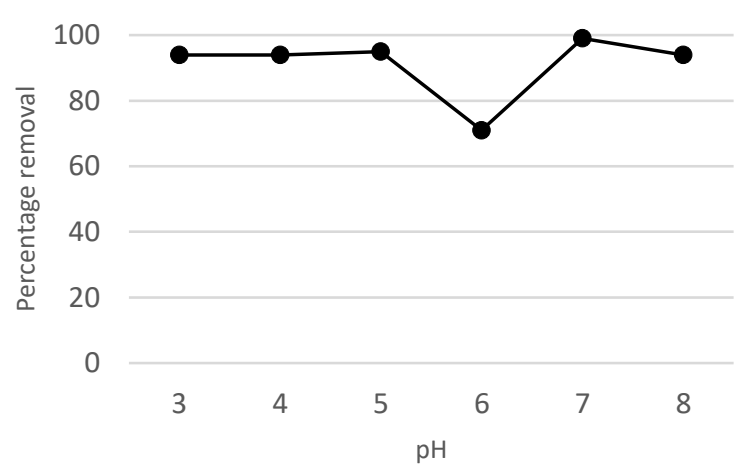

Fig. 4 Percentage removal of suspended solid of varied $\mathrm{pH}$ at dose PAC $3 \mathrm{~g} / \mathrm{L}$.

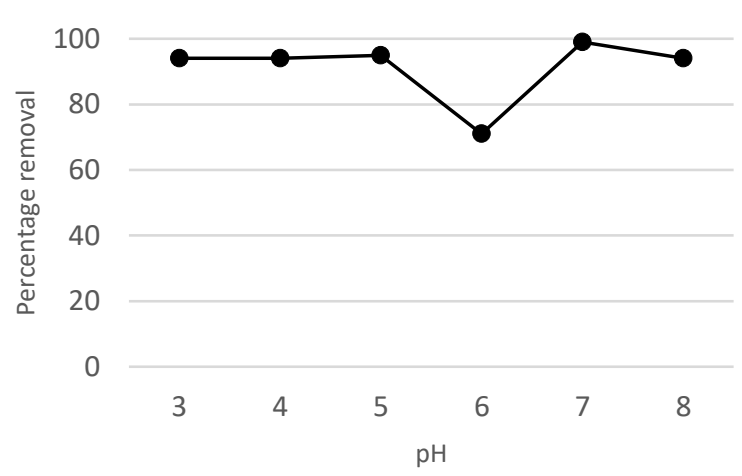

Fig. 4 Percentage removal of suspended solid of varied $\mathrm{pH}$ at dose PAC 3g/L. 


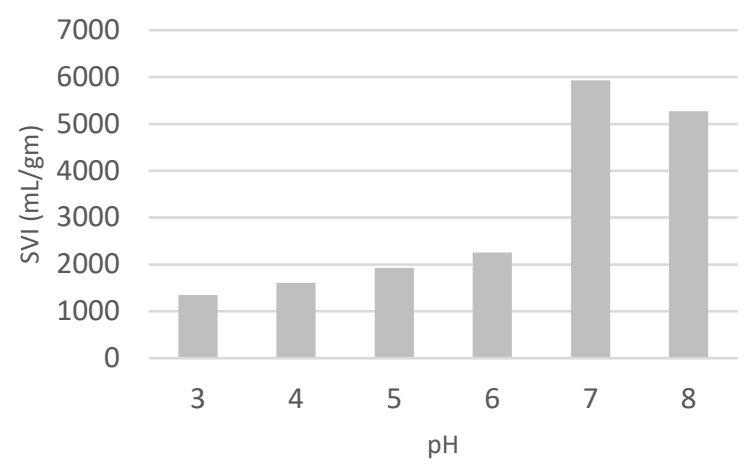

Fig. 5 - Sludge volume index of varied $\mathrm{pH}$ at dose PAC 3g/L.

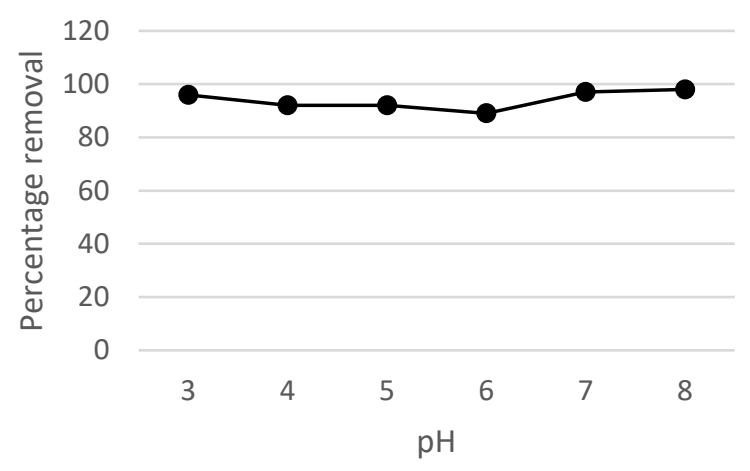

Fig. 7 - Percentage removal of suspended solid of varied $\mathrm{pH}$ at dose PAC $4 \mathrm{~g} / \mathrm{L}$.

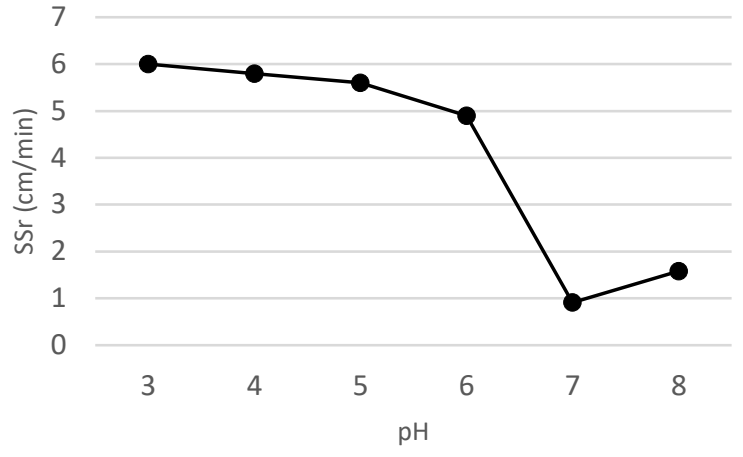

Fig. 6 - Sludge settling rate of varied $\mathrm{pH}$ at dose PAC 3g/L.

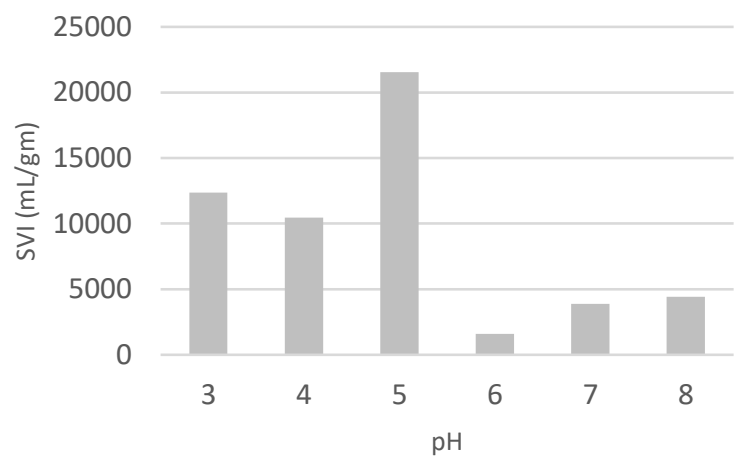

Fig. 8 - Sludge volume index of varied pH at dose PAC 4g/L.

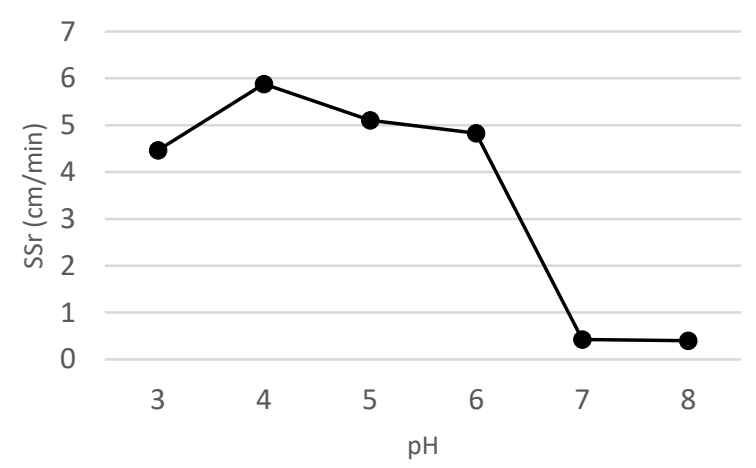

Fig. 9 - Sludge settling rate of varied pH at dose PAC 4g/L.

\subsection{Tapioca Flour}

In the case of tapioca flour as single coagulant, the experimental runs were conducted at $\mathrm{pH}$ 6. According to Zin et al. [15], the starch coagulant seems to be more efficient in acidic condition. Doses of tapioca flour with range $0.2 \mathrm{~g} / \mathrm{L}-$ $1.2 \mathrm{~g} / \mathrm{L}$ was used in this study to identify the optimum dosage. The maximum removal of suspended solids was observed at $\mathrm{pH} 6$ with dose of tapioca flour at $1 \mathrm{~g} / \mathrm{L}$ with percentage removal of $15.4 \%$ as shown in Fig. 10. The removal of suspended solid using tapioca flour was low.

Furthermore, it is clearly showing that, tapioca flour is not strong enough to remove the pollutant in leachate. At initial dose of $0.2 \mathrm{~g} / \mathrm{L}$ it seems there was minimal removal occurred and was increasing slightly till it reached the optimum dose and it goes down gradually. According to Alias et.al [16], there was no removal found at dose $0.2 \mathrm{~g} / \mathrm{L}$ and it is approximately similar to this. However, the optimum dosage for tapioca flour was $1 \mathrm{~g} / \mathrm{L}$. 
In terms of settle ability parameters, there was minimal sludge formation when using tapioca flour as a coagulant. This is because starch ions were not highly positive like the chemical coagulant to bond with negatively charged particles in leachate. Tapioca flour produce low floc volume and in terms of mechanism it was not charge neutralization, but it was more into particle bridging [17]. Thus, no data of SVI and SSR were recorded for tapioca flour.

After the varying the dosage of tapioca starch, $\mathrm{pH}$ adjustment was done to determine the optimum Moreover, according to Lo [18], a starch coagulant usually works well in highly acidic and alkaline conditions. The highest removal of suspended solid was recorded at $\mathrm{pH} 4$ as $13.3 \%$ shown in Fig. 11. The trend of graph was decreasing gradually till pH 7 and then $\mathrm{pH} 8$ the removal was increased slightly. This has proved, the justification of Lo [18] and Zin et al. [15], where the starch coagulant works well in acidic and alkaline condition. PH 4 was selected as optimum condition for TF.

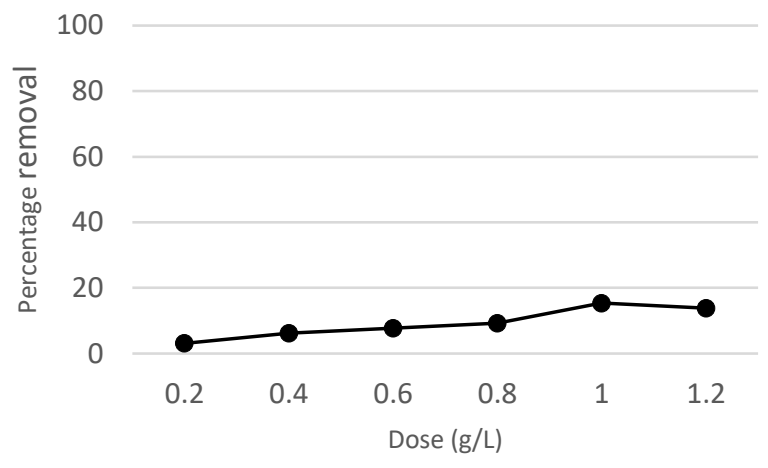

Fig. 10 - Removal of suspended solid of varied dose of tapioca flour at pH 6 .

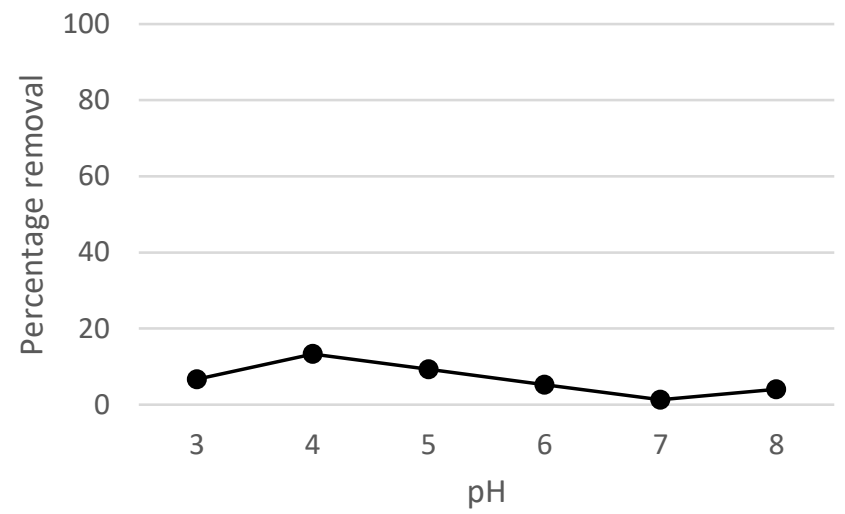

Fig. 11 - Removal of suspended solid of varied $\mathrm{pH}$ at dose $1.0 \mathrm{~g} / \mathrm{L}$ of tapioca flour.

\subsection{Scanning Electron Microscopic (SEM) of Sludge After Treatment}

Fig. 12 is a SEM image of sludge after treatment at dose $3 \mathrm{~g} / \mathrm{L}$ of PAC and $\mathrm{pH} 8$ of leachate. It was found that the floc was agglomerated into various size and shapes and the range size of particles were from $2.5 \mu \mathrm{m}$ to $10 \mu \mathrm{m}$. The shape of particles were nonuniform and shaped elongated. Furthermore, the floc formation looked compacted.

\subsection{Comparison of Percentage Removal of Suspended Solid Between Polyaluminium Chloride and Tapioca Flour as Single Coagulant}

Comparison of percentage removal was conducted as shown in Table 2. From Table 3, the most effective dose of PAC as single coagulant is $3 \mathrm{~g} / \mathrm{L}$ at $\mathrm{pH} 8$ and optimum dose for tapioca flour as single coagulant is $1 \mathrm{~g} / \mathrm{L}$ at $\mathrm{pH} 4$. The percentage removal by PAC as single coagulant in term of suspended solid is $94 \%$ compared with tapioca flour is only $13.3 \%$. Thus, it shows that PAC is more effectives than tapioca flour as single coagulant.

Polyaluminium chloride as single coagulant is more effective in removing suspended solid of leachate and has better formation of sludge compared to tapioca flour. Even though, there is a lot of advantages of using natural coagulant which has been discussed but in terms of removal of suspended solid and the efficiency is at stake compare the chemical coagulant, polyaluminium chloride. Hence, it is concluded that polyaluminium chloride has shown the potential as best 
coagulant compare to tapioca starch in terms of removal of suspended solid, sludge volume index and sludge settling rate.

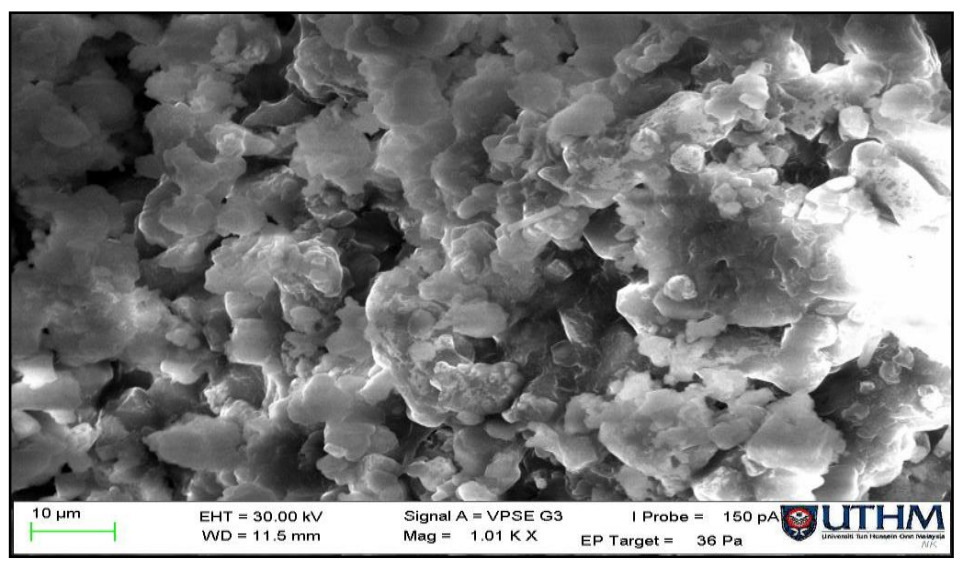

Fig. 12 - SEM image sludge leachate at dose 3g/L of PAC.

Table 3 - Comparison of percentage of removal of PAC and TS as single coagulant.

\begin{tabular}{|c|c|c|c|c|c|}
\hline Coagulant & $\mathbf{p H}$ & $\begin{array}{c}\text { Optimum } \\
\text { Dose (g/L) }\end{array}$ & $\begin{array}{c}\text { Percentage Removal of } \\
\text { Suspended Solid (\%) }\end{array}$ & $\begin{array}{c}\text { Sludge Volume } \\
\text { Index (mL/gm) }\end{array}$ & $\begin{array}{c}\text { Sludge Settling } \\
\text { Rate (cm/min) }\end{array}$ \\
\hline $\begin{array}{c}\text { Polyaluminium } \\
\text { Chloride (PAC) }\end{array}$ & 8 & 3 & 94 & 5273 & 1.58 \\
\hline $\begin{array}{c}\text { Tapioca flour/starch } \\
\text { ( TS) }\end{array}$ & 4 & 1 & 13.3 & No data & No data \\
\hline
\end{tabular}

\section{Summary}

The coagulation - flocculation process has shown the used of PAC as coagulant was more effective in landfill leachate treatment compared to tapioca flour. The optimum of PAC dosage is at $3 \mathrm{~g} / \mathrm{L}$ was observed and yields a good suspended solid (SS) removal and other settleability parameters. The removal of SS, SVI, and SSR for optimum PAC were $94 \%, 5273 \mathrm{~mL} / \mathrm{gm}, 1.58 \mathrm{~mL} / \mathrm{min}$, respectively. Results showed that PAC as single coagulant was more effective for leachate treatment. As for natural coagulant, Tapioca flour was ineffective as single coagulant and might works as coagulant aid in the leachate treatment.

\section{Acknowledgement}

The authors are very pleased and grateful to Universiti Tun Hussien Onn (UTHM) Malaysia and Ministry of Higher Education Malaysia through Fundamental Research Grant Scheme (FRGS) VOT 1570.

\section{References}

[1] Manaf, L. A., Samah, M. A. A. \& Zukki, N. I. M. (2009). Municipal solid waste management in Malaysia: Practices and challenges. Waste Management, 29, 2902-2906.

[2] Bohdziewicz, J., Neczaj, E. \& Kwarciak, A. (2008). Landfill leachate treatment by means of anaerobic membrane bioreactor. Desalination, 221, 559-565.

[3] Tyrrel, S. F., Leeds-Harrison, P. B. \& Harrison, K. S. (2002). Removal of ammoniacal nitrogen from landfill leachate by irrigation onto vegetated treatment planes. Water Research, 36, 291-299.

[4] Mahmud, Kashif, Md Delwar Hossain \& Shahriar Shams. (2012). Different treatment strategies for highly polluted landfill leachate in developing countries. Waste Management, 32, 2096-2105.

[5] Mahmud, K., Hossain, M. D. \& Shams, S. (2012). Different treatment strategies for highly polluted landfill leachate in developing countries. Waste Management, 32, 2096-2105.

[6] Nur, S. M. Z. \& Omar, A. M. (2017). Removals of colour and turbidity from stabilized leachate by using alum and glutinous rice flour dual coagulants. MATEC Web of Conferences, 138, 08003.

[7] Mohd-Asharuddin, S., Othman, N., Zin, N. S. M. \& Tajarudin, H. A. (2017). A chemical and morphological study of cassava peel: A potential waste as coagulant aid. MATEC Web of Conferences, 103, 06012.

[8] American Public Health Association, American Water Works Association (2015). WEF Standard methods for the examination of water and wastewater. America: APHA: 2015. 
[9] Renou, S., Givaudan, J. G., Poulain, S., Dirassouyan, F. \& Moulin, P. (2008). Landfill leachate treatment: Review and opportunity. Journal of Hazardous Materials, 150, 468-493.

[10] Ghafari, S., Aziz, H. A. \& Bashir, M. J. (2010). The use of poly-aluminum chloride and alum for the treatment of partially stabilized leachate: A comparative study. Desalination, 257, 110-116.

[11] Aziz, H. A., Daud, Z., Adlan, M. N. \& Hung, Y. T. (2009). The use of polyaluminium chloride for removing colour, COD and ammonia from semi-aerobic leachate. International Journal of Environmental Engineering, 1, 20-35.

[12] Zainol, N. A., Aziz, H. A., Yusoff, M. S. \& Umar, M. (2011). The use of polyaluminum chloride for the treatment of landfill leachate via coagulation and flocculation processes. Research Journal of Chemical Sciences, 1, 34-39.

[13] Domínguez, J. R., Beltrán de Heredia, J., González, T. \& Sanchez-Lavado, F. (2005). Evaluation of ferric chloride as a coagulant for cork processing wastewaters. Influence of the operating conditions on the removal of organic matter and settleability parameters. Industrial and Engineering Chemistry Research, 44, 6539-6548.

[14] Dominguez, J. R., Gonzalez, T., García, H. M., Sánchez-Lavado, F. \& de Heredia, J. B. (2007). Aluminium sulfate as coagulant for highly polluted cork processing wastewaters: Removal of organic matter. Journal of Hazardous Materials, 148, 15-21.

[15] N. S. M., Aziz, H. A. \& Tajudin, S. A. A. (2006). Performance of tapioca starch in removing suspended solid, colour and ammonia from real partially stabilized leachate by coagulation-flocculation method. ARPN Journal of Engineering and Applied Sciences, 11, 1-15.

[16] Ahmad, A. L., Sumathi, S. \& Hameed, B. H. (2006). Coagulation of residue oil and suspended solid in palm oil mill effluent by chitosan, alum and PAC. Chemical Engineering Journal, 118, 99-105.

[17] Bratby, J. (2006). Coagulation and Flocculation in Water and Wastewater Treatment. (UK: IWA publishing).

[18] Lo, M.R. (2012). Development and Application of Novel Coagulant from Oil Palm Trunk Waste for Semi-Aerobic Landfill Leachate Treatment, MSc Thesis. Universiti Sains Malaysia. 